\title{
Inland vessels emission inventory: distribution and emission characteristics in the Red River, Hanoi, Vietnam
}

\author{
Dat Nguyen, Anh Le Hoang, Minh Anh Nguyen Vu and \\ Viet Thanh Nguyen \\ Faculty of Environmental Sciences, VNU University of Science, Hanoi, Vietnam, and \\ Tram Anh Pham \\ Faculty of Environmental Sciences, VNU University of Science, Hanoi, Vietnam and \\ Department of Civil Engineering, Faculty of Engineering, University of Bristol, \\ Bristol, UK
}

\begin{abstract}
Purpose - Shipping is a major source of air pollution, causing severe impacts on the environment and human health, greatly contributing to the creation of greenhouse gases and influencing climate change. The research was investigated to provide a better insight into the emission inventories in the Red River in Hanoi (Vietnam) that is often heavily occupied as the primary route for inner-city waterway traffic.

Design/methodology/approach - The total emissions of seven different pollutants $\left(\mathrm{PM}_{10}, \mathrm{PM}_{2.5}, \mathrm{SO}_{\mathrm{x}}, \mathrm{CO}\right.$, $\mathrm{CO}_{2}, \mathrm{NO}_{\mathrm{x}}$ and $\mathrm{HC}$ ) were estimated using the SPD-GIZ emission calculation model.

Findings - The results show that $\mathrm{CO}_{2}$ has the most significant contribution to the gas volume emitted: 103.21 tons/day. Remarkably, bulk carriers are the largest emission vehicle, accounting for more than $97 \%$ of total emissions, due to their superior number and large capacity.

Social implications - The result to have a roadmap for making efforts to fulfil its commitment so that it could achieve its net-zero climate target by 2050 in Vietnam as committed at COP26.

Originality/value - In this research, the number of vehicles and types of vessels travelling on the Red River flowing within Hanoi territory and other activity data are reported. The tally data will be used to estimate emissions of seven different pollutants $\left(\mathrm{PM}_{10}, \mathrm{PM}_{2.5}, \mathrm{SO}, \mathrm{CO}, \mathrm{CO}_{2}, \mathrm{NO}_{\mathrm{x}}\right.$ and $\left.\mathrm{HC}\right)$ using a method combining both top-down and bottom-up approaches.
\end{abstract}

Keywords Emission inventory, Inland vessels, Red River, Vietnam

Paper type Research paper

\section{Introduction}

Shipping, a significant share of the global cargo is transported by waterways, which is a very important factor in the economic growth over the world (Ivče et al., 2019; Thach, 2014). Vessels sailing on inland rivers, lakes, canals and reservoirs include the categories listed for oceangoing ships, but in most coastal countries a higher proportion of smaller boats and recreational watercraft prevail (Ivče et al., 2019). Today, waterways transportation is one of the most economical and least pollutant emissions measured by

(C) Dat Nguyen, Anh Le Hoang, Minh Anh Nguyen Vu, Viet Thanh Nguyen and Tram Anh Pham. Published in Frontiers in Engineering and Built Environment. Published by Emerald Publishing Limited. This article is published under the Creative Commons Attribution (CC BY 4.0) licence. Anyone may reproduce, distribute, translate and create derivative works of this article (for both commercial and noncommercial purposes), subject to full attribution to the original publication and authors. The full terms of this licence may be seen at http://creativecommons.org/licences/by/4.0/legalcode

This research was funded by the Vietnam National University, Hanoi (VNU), under the project number QG.21.20.

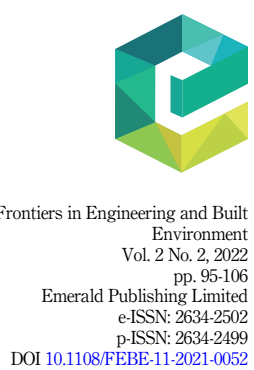


FEBE

2,2

ton-km tonnage of goods transported (Thach, 2014). On average, as measured in ton- $\mathrm{km}$, shipping by waterways can save fuel from 3.5 to 4.0 times compared to road transportation and up to 1.5 times compared to rail transportation (Blancas and El-Hifnawi, 2014). In Vietnam, estimated results by Blancas and El-Hifnawi (2014) sent to the World Bank showed that the inland waterway transport by 2030 will only be second to road transportation with $35 \%$ of the total volume of the goods transported, corresponding to 395 million tons/year. Nevertheless, the inland waterway transport means Vietnam are mainly small-capacity vessels, many of which are self-constructed and unregistered, making them difficult to be managed (Blancas and El-Hifnawi, 2014; JICA, 2010). Furthermore, cheap and poor-quality fossil fuels (diesel, coal, etc.) are often used to operate vessels (MONRE, 2016). The combustion of these fuels produces various air pollutants (i.e. black carbon - $\mathrm{BC}$, particulate matters $\mathrm{PM}_{10}, \mathrm{PM}_{2.5}, \mathrm{SO}_{2}$ ), greenhouse gases (including $\mathrm{CO}_{2}, \mathrm{~N}_{2} \mathrm{O}, \mathrm{CH}_{4}$ ) and other gases. In order to appreciate the contribution of these pollutants to the total local emissions, it is necessary to conduct an emissions inventory (EI) (Khue et al., 2019; Le et al., 2020).

Consequently, to manage air quality, $\mathrm{EI}$ is an essential task that needs to be carried out (MONRE, 2016). In Vietnam, there is currently no national EI programme (Le et al., 2020; MONRE, 2021). However, EI in scientific research for one or a few specific fields have been conducted in several cities, such as Hanoi, Ho Chi Minh, Bac Ninh and Can Tho. Significantly, the EI for inland vessels is limited within research conducted in the Me Kong River Delta area, including Ho Chi Minh City (Bang et al., 2019; Khue et al., 2019) and Can Tho (Bang et al., 2018). However, it is not conducted in the Red River Delta area (RRD). Furthermore, most vessels EI research were conducted only in ports with ocean-going vessels (OGVs), and calculations for emissions from smaller vessels operating in the river were still missing, such as the research in Can Tho (Bang et al., 2018). In this research, the number of vehicles and types of vessels travelling on the Red River flowing within Hanoi territory and other activity data are reported. The tally data will be used to estimate emissions of seven different pollutants (including $\mathrm{PM}_{10}, \mathrm{PM}_{2.5}, \mathrm{SO}_{\mathrm{x}}, \mathrm{CO}, \mathrm{CO}_{2}, \mathrm{NO}_{\mathrm{x}}$ and $\mathrm{HC}$ ) using a method combining both top-down and bottom-up approaches.

\section{Methodology}

\subsection{Study area and framework}

Hanoi currently has seven long interprovince rivers flowing through its territory (Red River, Duong River, Da River, Nhue River, Cau River, Day River and Ca Lo River). Inside the city, there are three short rivers (To Lich River, Kim Nguu River and Tich River) and two small, narrow rivers (Set and Lu River) (Bao et al., 2019). However, only the Red River and Duong River are the main corridors in the North Vietnam river system with vessel activities (Blancas and El-Hifnawi, 2014). Significantly, the Red River is the largest and most important among rivers flowing through Hanoi as it is a water supply source for all remaining rivers. Therefore, we only carry out an EI on the Red River.

The Red River (RRI, Sông Hồng in Vietnamese) runs in three countries, including Vietnam, Laos and China, with a total watershed of $156.451 \mathrm{~km}^{2}$ and flows $1,200 \mathrm{~km}$ south-eastward (Trinh et al., 2017). A part of the $130 \mathrm{~km}$ long river, out of the total $510 \mathrm{~km}$ in Vietnam, runs from northwest to southeast in Hanoi capital (Figure 1) that was selected as a study area; hereinafter it is noted as RRH.

The RRH is knowledge as it is an arterial waterway of RRD in Vietnam. Downstream, the $\mathrm{RRH}$ expands and has many convenient tributaries for trade, attracting an overwhelming number of water means of transport. The investigation involved tallying the number of waterway vehicles and surveying to determine the total emission of the RRH. The technical route for the estimate of an air pollutant emission for the inland vessels of the RRH is shown in 

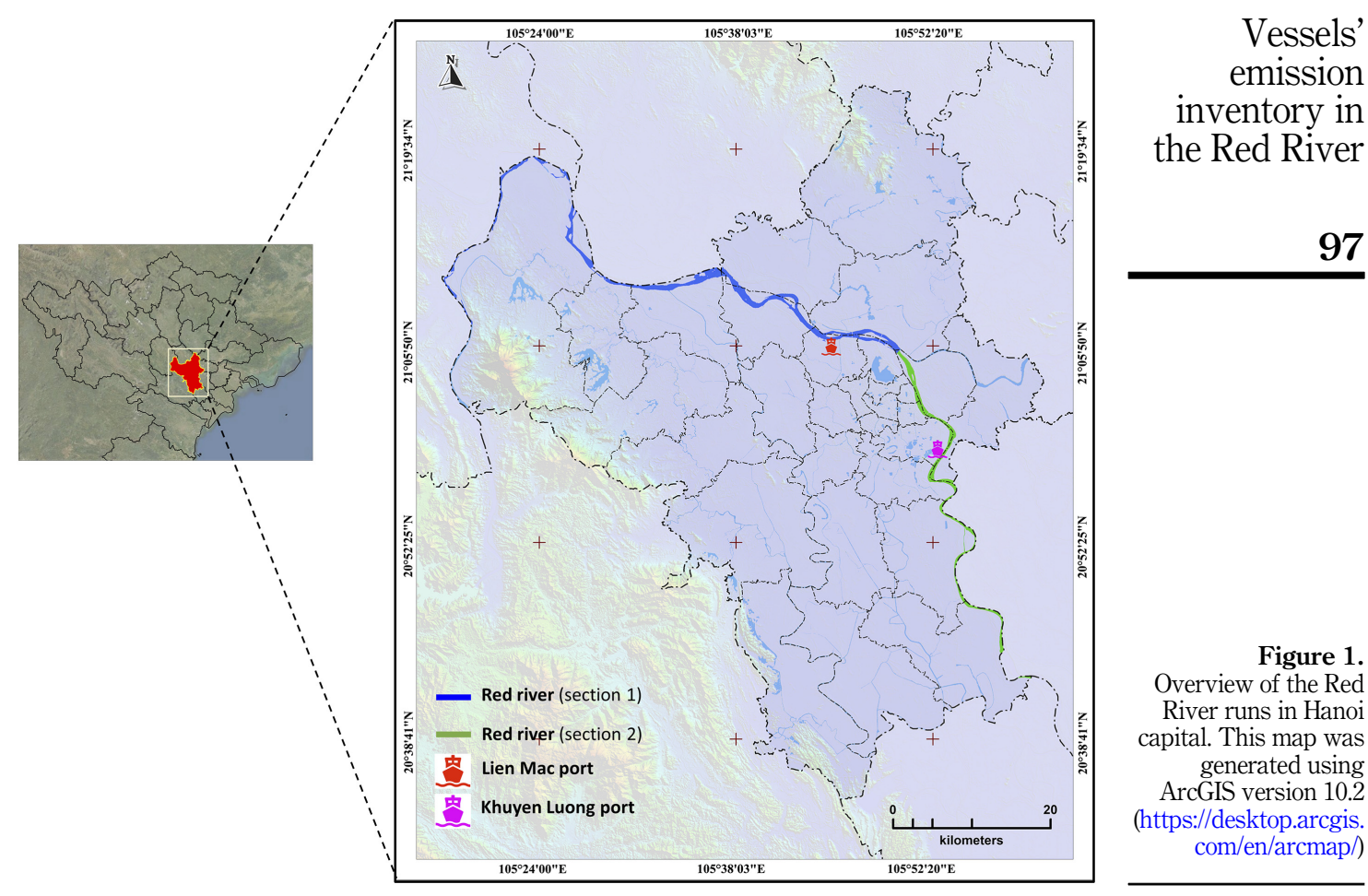

Figure 2. To investigate the EI, it was separated into three phases as shown in Figure 2, those are including study area selection, data collection and emission estimation.

\subsection{Data collection}

2.2.1 Investigation data. To investigate the EI for inland vessels transportation on the RRH, the method used both activity data and emission factors (EF). The study area (Figure 1) was separated into two sections for accounting. The first section (S1), $71.35 \mathrm{~km}$ long, starts from where the RRI joins Hanoi (Phong Van commune, Ba Vi district) to where the Duong river branches from RRI (Ngoc Thuy commune, Gia Lam district). At the end of S1, many vessels enter the RRI from the Duong river and vice versa. Thus, the number of vessels on the RRH changes markedly will affect the total emission of the study area. The second section (S2), 2, $57.11 \mathrm{~km}$ long, connects with S1 and follows the downstream till the end of Hanoi area (Quang Lang commune, Phu Xuyen district).

Subjects selected for the study include two main types of vessels on the RRH: bulk carrier and ferry. Ferry is mainly divided into two classes: Class I includes large vessels that allow cars to get on, and class II includes smaller vessels that can only transport people and small motorized vehicles such as motorbikes and bicycles across the river. The larger the vessel, the larger the capacity, and it will affect the emissions more severely. Notably, ferries only move horizontally between the two sides of the river to serve the travel needs of people, while the other type of vessel moves along the stream and mainly carries local produce, coal and building material.

The daily number of bulk carriers was simultaneously counted at two sites, Lien Mac port and Khuyen Luong port, representing the S1 and S2, respectively (Figure 1). These are 
FEBE

2,2

98

Figure 2.

Technical route to obtain inland vessel EI of the Red River in Hanoi capital

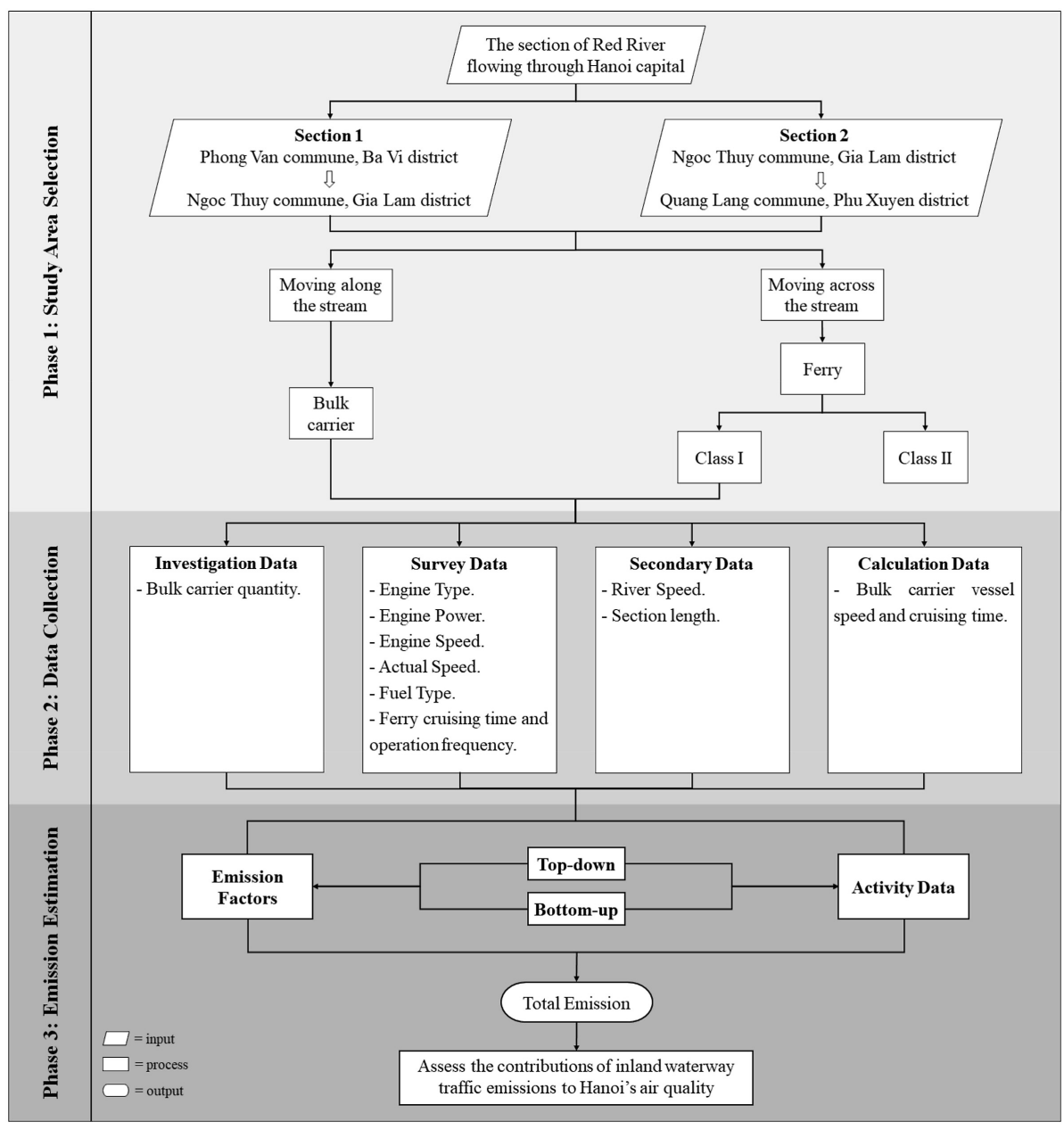

two major ports of Hanoi, so they attract a noticeable number of vessels. In particular, they have convenient locations and clear views, suitable for research teams to conduct the tallying process. The hydro-meteorological characteristics of North Vietnam influenced the $\mathrm{RRH}$ hydrological regime. Usually, the flood season (rainy season) is from May to October, and the dry season is from November to May of the following year (Blancas and El-Hifnawi, 2014). Therefore, the dry season in the study area includes six months, equivalent to about 180 days per year. During the dry season, low water levels and river speed in the RRH make navigation difficult (Blancas and El-Hifnawi, 2014). However, the tallying process was still conducted on 3 April 2021, because it rained in Hanoi the previous days, causing the riverbed water level to rise, creating favourable conditions for waterway transportation. Thereby, the study results could represent the emissions from vessels at the RRH on days with high traffic.

The project selected a tallying method in EI for the following reason: Vessels on the RRH originate from many localities, and many do not have registration numbers. As a result, the 
data of inland waterway vehicle quantities from national registry centres will be incomplete. Therefore, the direct tally of the vehicles appearing at each section will allow collecting the exact number of vehicles compared to reality. The number of vehicles counted during the study period is presented in Table 1 .

2.2.2 Vessel parameters. Engine power data recorded on the registration certificate of inland waterway vessels are inaccurate because the vessels in the study area are usually tuned to improve productivity. Hence, to collect data that is accurate and consistent with the current state of the study area, data on engine power, maximum speed and actual speed are collected by questionnaire and later averaged. The average values of engine power, engine speed and actual speed are shown in Table 2.

2.2.3 Emission factors selection parameter. Data on round per minute (RPM) and fuel type were collected in the survey to select the EFs. The RPM value, available for approximately $68 \%$ of the main engines, was used to determine if the engine is high-speed diesel (with $\mathrm{RPM}>1,000$ ), medium speed (with $300<\mathrm{RPM} \leq 1,000$ ) or slow speed (with $\mathrm{RPM} \leq 300$ ) speed (ENTEC, 2010). Based on the survey results, most vessels operating on the RRH have an RPM of more than 1,000 and use cheap diesel fuel. Thus, most engines in the study framework are high-speed diesel type and operate with marine gas oil $0.5 \% \mathrm{~S}$, commonly sold at gas stations for trucks and diesel-powered equipment.

2.2.4 Ferries activity data. To gather information on operating frequency, we surveyed ticket gatekeepers of each ferry pier. Then, the number of ferry rides during the study period was calculated based on the survey data and considered similar across piers. In this study, ferry operation is analysed with two modes: cruising and hotelling, in which hotelling emissions were estimated to capture emissions from vessels while waiting at the piers before departure (Winijkul, 2020). Every time ferries enter hotelling mode, they are stationary, but the engine is still running, affecting the emission capacity. The activity data of ferries are shown in Table 3.

2.2.5 River flow rate. In this study, only an EI of waterway transport vehicles in the dry season was conducted so that the river flow rate value will be averaged at $1.99 \mathrm{~km} / \mathrm{h}$ (VMHA, 2021). The river flow rate value was not directly used to estimate emissions in the Sustainable Port Development (SPD) model created by the Deutsche Gesellschaft für Internationale Zusammenarbeit (GIZ, 2015) (hereinafter, SPD-GIZ model). However, the study conducted an EI for vessels traveling with/against the river currents. Thus, the river flow rate value was used to calculate vessel speed affected by the river currents.

2.2.6 Vessel speed. When vessels move against significant river currents, the vessel speed should be calculated based upon the following: for vessels travelling with the river current,

\begin{tabular}{|c|c|c|c|c|}
\hline Traveling direction & Section 1 & Bulk carrier quantity & Section 2 & Table 1. \\
\hline $\begin{array}{l}\text { With the river current } \\
\text { Against the river current }\end{array}$ & $\begin{array}{l}294 \\
147\end{array}$ & & $\begin{array}{r}196 \\
65\end{array}$ & $\begin{array}{l}\text { Total number of bulk } \\
\text { carriers obtained from }\end{array}$ \\
\hline
\end{tabular}

\begin{tabular}{|c|c|c|c|c|c|c|}
\hline \multirow{2}{*}{\multicolumn{2}{|c|}{ Vessel type }} & \multirow[b]{2}{*}{ Engine power $(\mathrm{kW})$} & \multirow[b]{2}{*}{ Engine speed (km/h) } & \multicolumn{2}{|c|}{ Actual speed (km/h) } & \multirow{4}{*}{$\begin{array}{r}\text { Table } 2 . \\
\text { Average values of } \\
\text { vessel parameters } \\
\text { based on the } \\
\text { surveyed data }\end{array}$} \\
\hline & & & & Cruising & Hotelling & \\
\hline Ferry & Class I & 100 & 18 & 7 & 0 & \\
\hline \multicolumn{2}{|c|}{ Bulk carrier } & 235 & 20 & 10 & 10 & \\
\hline
\end{tabular}


FEBE

2,2

\begin{tabular}{llclccr}
\hline ID & Ferry pier & Section & Class & Ferry ride quantity & $\begin{array}{c}\text { Time (hour) in } \\
\text { mode/ride }\end{array}$ \\
\hline 1 & Co Do & 1 & II & 84 & 0.10 & 0.03 \\
2 & Van Phuc & 1 & I & & & \\
3 & Tho Phan - Chu An & 1 & I & & \\
4 & Lien Ha - Lien Trung & 1 & II & & \\
5 & Kim Lan & 2 & II & & \\
6 & Van Duc & 2 & II & & \\
7 & Van Phuc - Duong Liet & 2 & I & & \\
8 & Xam Duong - Xam Hong & 2 & I & & \\
9 & Me So & 2 & I & & \\
10 & Hong Van - Binh Minh & 2 & I & & \\
11 & Chuong Duong - Tu Dan & 2 & I & & \\
12 & An Canh - Nam Mau & 2 & I & & \\
13 & Dap - Tan Chau & 2 & I & & \\
14 & Van Nhan - Dong Ninh & 2 & I & & \\
15 & Dai Tap & 2 & I & & \\
16 & Vuon Chuoi & 2 & I & & \\
17 & Khai Thai - Mai Dong & 2 & I & & \\
18 & Giang & 2 & I & & \\
\end{tabular}

Table 3.

Activity data of ferry piers

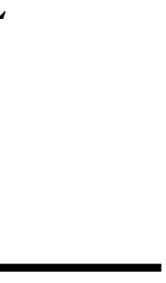

$\underline{100}$

the vessel speed should be the actual speed plus the river speed; for vessels travelling against the river current, the vessel speed should be the actual speed minus the river speed (US EPA, 2009). Thus, the vessel speed values of each type of vessel are calculated and shown in Table 4.

2.2.7 Bulk carrier cruising time. For vessels moving along the stream, this research only conducted cruising mode EI. Due to numerous vessels coming from different locations, and most of them being spontaneous activities, it was not possible to know the full schedule of all vessels. The cruising time of each vessel type was calculated by dividing the length of each section by the vessel speed. The vessel found in any section of the study area in the tallying process is considered to have travelled that whole section with the cruising time shown in Table 4 . This was slightly problematic in that: there could be errors for vessels that do not travel the entire stretch as previously assumed. However, after an actual investigation, it is discovered that vessels tend to pass through the study area and do not stop at any point inside this area. This finding helps to reduce errors, and the research results are reasonably robust.

\subsection{Emission inventory}

Emissions for inland vessels of the RRH were estimated using the SPD-GIZ model. The SPDGIZ model is a product of technical cooperation between the ASEAN region and Germany.

\begin{tabular}{lcccc}
\hline & \multicolumn{2}{c}{ Section 1 } & \multicolumn{2}{c}{ Section 2 } \\
& $\begin{array}{c}\text { Traveling with the } \\
\text { river current }\end{array}$ & $\begin{array}{c}\text { Traveling against } \\
\text { the river current }\end{array}$ & $\begin{array}{c}\text { Traveling with the } \\
\text { river current }\end{array}$ & $\begin{array}{c}\text { Traveling against } \\
\text { the river current }\end{array}$ \\
\hline $\begin{array}{l}\text { Bulk carrier } \\
\text { vessel speed }\end{array}$ & 11.99 & 8.01 & 11.99 & 8.01 \\
$\begin{array}{l}\text { Bulk carrier } \\
\text { activity time }\end{array}$ & 5.95 & 8.91 & 4.76 & 7.13 \\
\hline
\end{tabular}

Table 4.

Calculated bulk carrier speed $(\mathrm{km} / \mathrm{h})$ and activity time (h) 
It applied the vessel's EI methodologies suggested by US EPA (US EPA, 2009). The model was proved to be perfectly suitable for Vietnamese waterways EI conditions as it has been successfully applied to calculate emissions for the port system in Ho Chi Minh City (Bang et al., 2019; Khue et al., 2018). In essence, the SPD-GIZ model is a well-designed Excel spreadsheet with pre-programmed commands and functions, making it like a completed emissions calculation programme. The only work that needs to be done is to enter vessel information and activity data collected from the tallying process into the model. Based on the input data, engine EFs could be looked up automatically. Later, emissions for cruising and hotelling conditions were calculated by modified equations such as Equations (1) and (2).

$$
\begin{gathered}
E=P * L F * A * E F^{*} 10^{-6} \\
L F=(A S / M S)^{3}
\end{gathered}
$$

where $E$ is emissions (tons); $P$ is maximum continuous rating power $(\mathrm{kW}) ; L F$ is load factor (per cent of vessel's total power); $A$ is activity $(h) ; E F$ is emission factor $(\mathrm{g} / \mathrm{kWh}) ; A S$ is actual speed (knots) and $M S$ is maximum speed (knots). The EFs used in this study include both EFs under cruising and EFs under hotelling conditions referenced from the US EPA's protocol (US EPA, 2009).

\section{Results and discussion}

\subsection{Estimation of total air pollutants emission}

Based on activity data collected, the SPD-GIZ model illustrated the total emissions of seven different pollutants. Thus, the daily emissions of $\mathrm{PM}_{10}, \mathrm{PM}_{2.5}, \mathrm{SO}_{\mathrm{x}}, \mathrm{CO}, \mathrm{CO}_{2}, \mathrm{NO}_{\mathrm{x}}$ and $\mathrm{HC}$ are $0.052,0.048,0.32,0.23,103.21,2.05$ and 0.11 tons/day, respectively. It could be seen that $\mathrm{CO}_{2}$ has the most significant contribution to the gas volume emitted, 103.21 tons/day, due to $\mathrm{CO}_{2}$ having the most prominent EF out of all seven air pollutants. In contrast, hydrocarbons (HC) have a low emission volume, only about 0.11 tons/day. According to the data in Figure 3, as expected, in good agreement with Reşitoğlu et al. (2015), $\mathrm{NO}_{\mathrm{x}}$ has the highest proportion of vessel pollutant emissions with a rate of $74.21 \%$. Nevertheless, in contradiction to Reşitoğlu et al. (2015), after $\mathrm{NO}_{\mathrm{x}}$ emissions, $\mathrm{SO}_{\mathrm{x}}$ has the second-highest proportion in pollutant emissions due to the fact that sulphur dioxide $\left(\mathrm{SO}_{2}\right)$ could be released during the combustion process of high sulphur content fuels (Reşitoğlu et al., 2015).

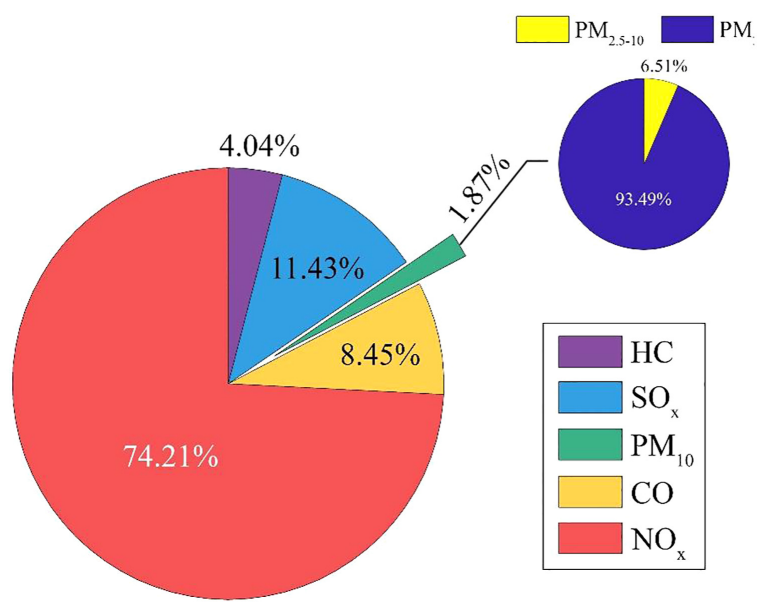

Figure 3. emissions (\%) 
FEBE

2,2

102
3.2 Emission in two river sections (S1 and S2)

After the fieldwork and observing the vessels' navigation habits, the study area was divided into two sections: The location where Duong River is branching from the RRI was chosen to separate the two sections. As can be seen in the bar chart from Figure 4, it is important to note that the total emissions of bulk carriers are twice as in the S1 compared to the S2. In contrast, emissions from ferries in the S2 will be more outstanding than in the $\mathrm{S} 1$. The S2 has significantly few major road bridges over the river, making ferries the primary means of transport for people to move across the river. Therefore, the $\mathrm{S} 2$ has more ferry piers than the $\mathrm{S} 1$ and mostly only class I ferries can be seen here. The emissions from class II ferries are equal since both sections have the same number of class II ferries piers. However, the emissions from both classes of passenger ferries are minimal and insignificant compared to those from bulk carriers. So, although the emissions from the ferries in the S2 are more significant compared to S1, data in the pie chart from Figure 4 suggest that total emissions in the S1 are much more abundant than those in the S2. All pollutants emission in the $\mathrm{S} 1$ accounts for more than $67 \%$. In addition, this disparity is due to the sudden change in vehicles where the Duong River branches from the RRI. Many vessels travel through the S1 but do not move through the S2 and turn into the Duong River. Thus, the vessels in the S2 are significantly reduced compared to the S1, leading to notable emissions in the S1.

\subsection{Emissions by vessel types}

The subjects of this study include bulk carrier, class I ferry and class II ferry. Each has different technical specifications, activity data and the number of vessels operating during the study period, causing extreme discrepancies in emissions between vessel types. Total emissions as categorized by vessel type are shown in Figure 5. The results show that bulk carriers are the largest emission vehicle (accounting for more than $97 \%$ of total emissions) due to their superior number and large capacity. Meanwhile, class II and class I ferries were only responsible for nearly 0.5 and $2.5 \%$ respectively. The total emissions of the study area were mainly contributed by vessels travelling along the river with about $97 \%$. Otherwise, passenger ferries have negligible emissions: only nearly $3 \%$ of total emissions.
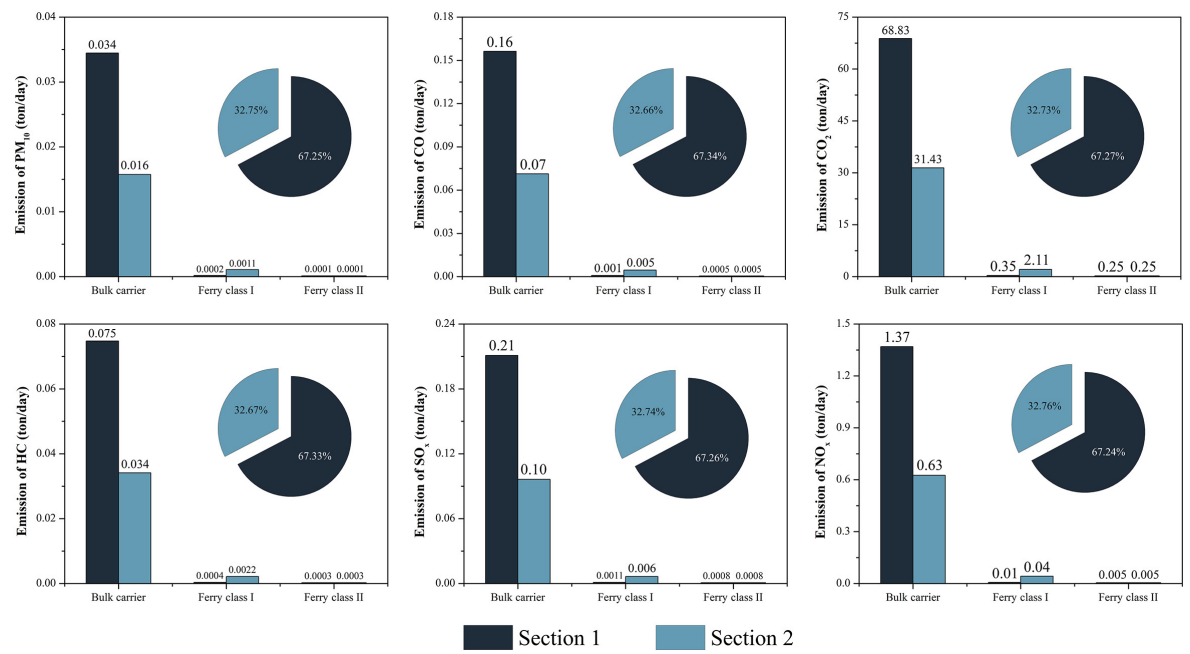

Figure 4 .

Total emission in two river sections 

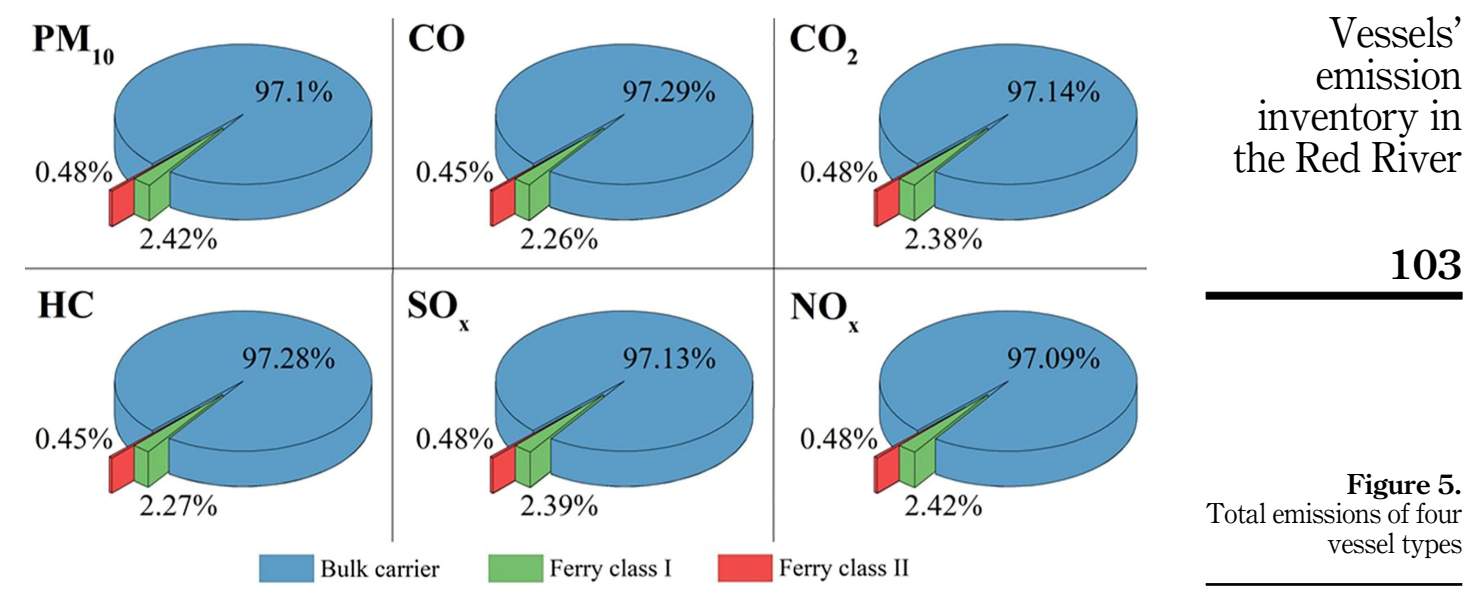

\subsection{Emission on vessels affected by river currents}

Vessels in the study area were evaluated according to two types of movement: moving along the stream and moving across the stream, in which, vessels that move along the stream are affected by the river currents. It is clear from Figure 6 that vessels travelling with the currents are the primary source of emissions among vessels that move along the stream, accounting for $60.21 \%$. Meanwhile, emissions from vessels travelling against the currents account for $39.79 \%$. Our results are in significantly good agreement with (JICA, 2010): Waterway transport from the west of Hanoi mainly carries goods downstream and returns without cargo (empty) (JICA, 2010). The tally data also shows that the number of vessels travelling

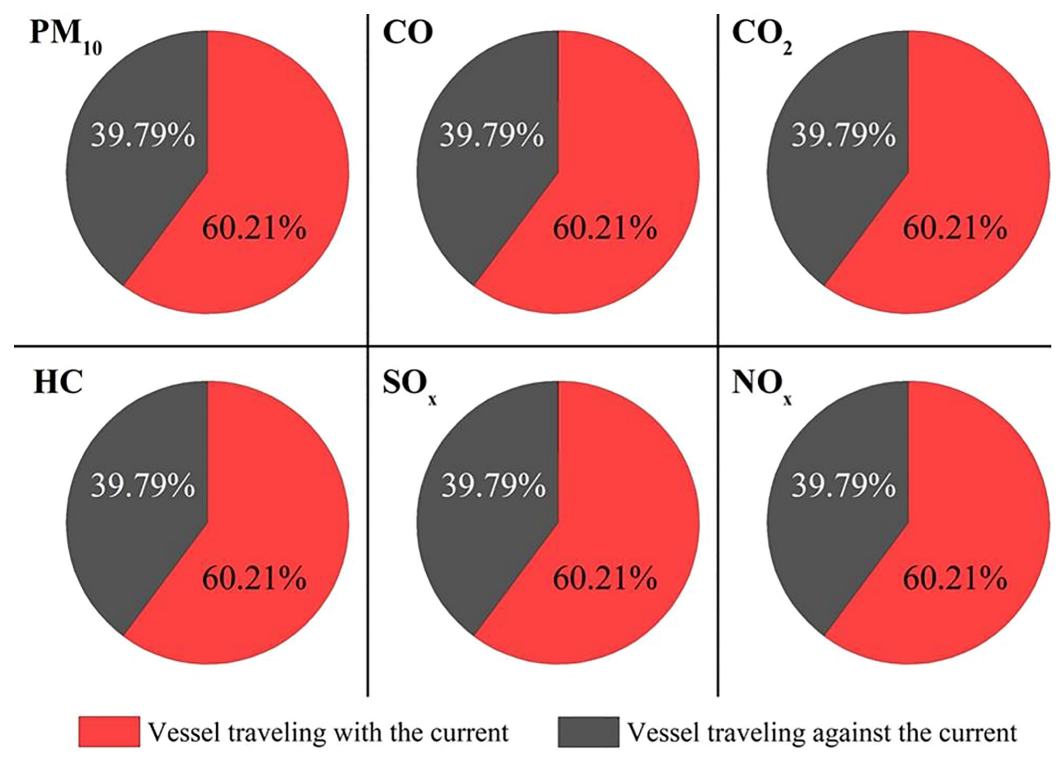

Figure 6.

Total emissions between vessels travelling with the currents and vessels travelling against the currents 
FEBE

2,2

\section{4}

with the current is much higher than that travelling against the current, causing significant emissions differences.

\subsection{Emission on two operation modes}

In our study, ferries moving across the river were inventoried in two operation modes: cruising and hotelling. Our results differ from those in the previous study by Winijkul (2020) as our study shows that cross-river ferries $\mathrm{PM}_{2.5}$ emissions in the hotelling mode were higher than those in cruising mode. For emissions shared between cruising and hotelling conditions (Figure 7), the emissions from hotelling dominated as their figures are almost double. In contrast, the percentage of $\mathrm{HC}$ emissions in cruising is higher (60.46 vs $39.54 \%$ ). While the number of $\mathrm{CO}$ emission coming from these two types are almost the same at approximately $50 \%$. It is notable that both hotelling and cruising (release the same amount of $\mathrm{NO}_{\mathrm{x}}, \mathrm{CO}_{2}, \mathrm{SO}_{\mathrm{x}}$ ) about 70 and $30 \%$ respectively. This difference refers to the significant distinction between the actual cruising speed and maximum speed in both classes of ferries. Due to the short travel distance per ride (about 600 meters), ferries only operate at a very low actual speed (7 $\mathrm{km} / \mathrm{h}$ ) compared to the maximum speed $(18 \mathrm{~km} / \mathrm{h})$. Hence, the ferries' main engine load factor in cruising mode is tiny, making emissions were reduced.

\section{Conclusions}

Air pollutants EI for inland vessels on the RRH were estimated using the SPD-GIZ emission calculation model. The results show that the largest amount of gas emitted from this activity is $\mathrm{CO}_{2}$ (103.21 tons/day). The rest includes $\mathrm{PM}_{10}, \mathrm{PM}_{2.5}, \mathrm{SO}_{\mathrm{x}}, \mathrm{CO}, \mathrm{NO}_{\mathrm{x}}$ and $\mathrm{HC}$ with an emission of $0.052,0.048,0.32,0.23,2.05$ and 0.11 tons/day, respectively. It is also remarkable that bulk carrier is the largest emission vehicle type, accounting for more than $97 \%$ of total emissions. In the future, it is necessary to have comprehensive studies and annual EI generated for waterway vehicles to develop a more comprehensive national clean air programme.
Figure 7.

Total emissions between cruising and hotelling conditions

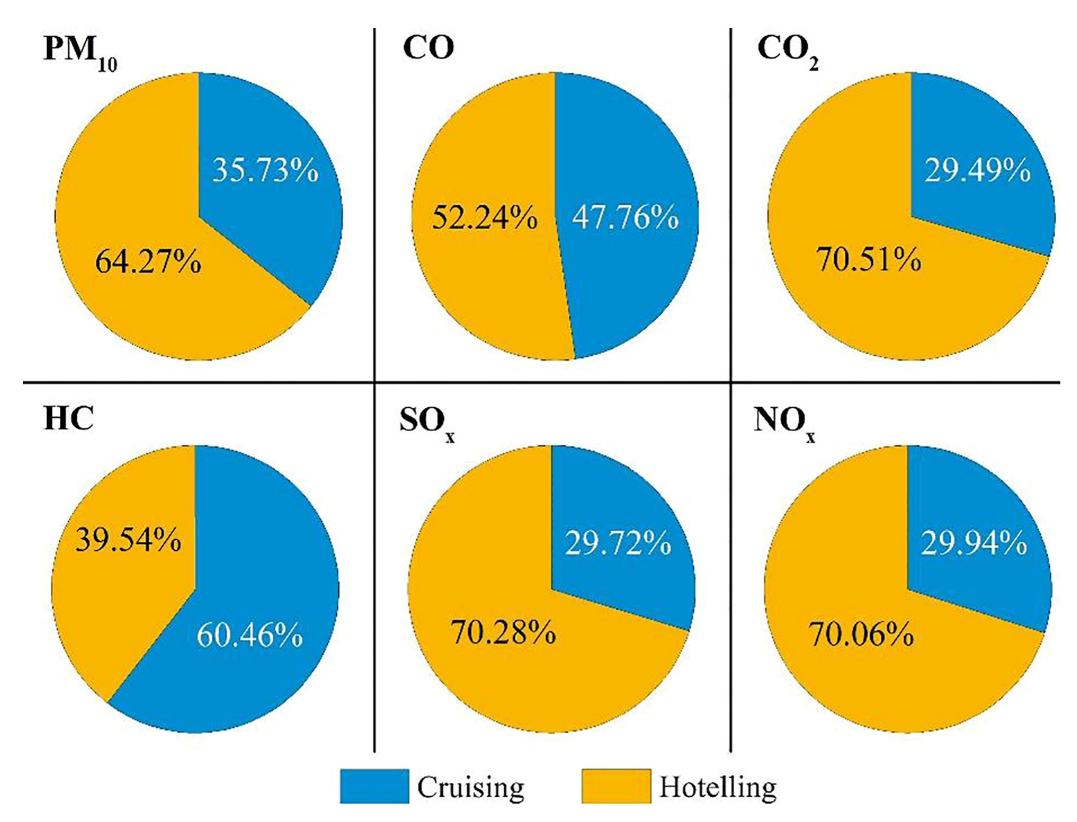




\section{References}

Bang, H.Q., Khue, V.H.N., Tam, N.T. and Lasko, K. (2018), "Air pollution emission inventory and air quality modeling for Can Tho City, Mekong Delta, Vietnam”, Air Quality, Atmosphere and Health, Vol. 11 No. 1, pp. 35-47, doi: 10.1007/s11869-017-0512-x.

Bang, H.Q., Khue, V.H.N., Tam, N.T., Hang, N.T.T. and Thuy, N.T.T. (2019), "A combination of bottom-up and top-down approaches for calculating of air emission for developing countries: a case of Ho Chi Minh City, Vietnam", Air Quality, Atmosphere and Health, Vol. 12 No. 9, pp. 1059-1072, doi: 10.1007/s11869-019-00722-8.

Bao, D.V., Bac, D.D., Hieu, N., Hieu, N., Dang, K.B. and Dang, K.B. (2019), Lakes and Rivers in Hanoi, Hanoi Publishing House, Hanoi.

Blancas, L.C. and El-Hifnawi, M.B. (2014), Facilitating Trade through Competitive, Low-Carbon Transport: The Case for Vietnam's Inland and Coastal Waterways. Directions in Development Countries and Regions, World Bank, Washington, District of Columbia.

ENTEC (2010), "UK ship emissions inventory", available at: https://uk-air.defra.gov.uk/assets/ documents/reports/cat15/1012131459_21897_Final_Report_291110.pdf (accessed 18 August 2021).

GIZ (2015), Best Practices on Environmental Management - Indicator 1. Sustainable Port Development in the ASEAN Region Project, Gesellschaft für Internationale Zusammenarbeit, Ho Chi Minh.

Ivče, R. Zekić, A. Radonja, R. and Reljac, B. (2019), "Emission inventory of ships calling at the Port of Bršica (Bay of Raša)", paper presented at the 2019 International Symposium ELMAR, Zadar, Institute of Electrical and Electronics Engineers (IEEE), pp. 163-166.

JICA (2010), Vietnam National Transport Strategy Study (VITRANSS 2), Specialized Report No. 04: Inland Waterway Transportation, Ministry of Transport (MOT), Hanoi.

Khue, V.H.N., Thanh, P.T.N., Bang, H.Q., Tam, N.T. and Hang, N.T.T. (2018), “Air emission inventory and application TAPM-AERMOD models to study air quality from 34 ports in Ho Chi Minh City", Science and Technology Development Journal-Science of The Earth and Environment, Vol. 2 No. 2, pp. 97-106, doi: 10.32508/stdjsee.v2i2.498.

Khue, V.H.N., Dung, H.M., Tam, N.T., Hang, N.T.T. and Bang, H.Q. (2019), "Inventory and mapping the air emissions from transportation activities in Ho Chi Minh city", Science and Technology Development Journal - Natural Sciences, Vol. 3 No. 2, pp. 100-114, doi: 10.32508/stdjns.v3i2.687.

Le, H.A. Phuong, D.M. and Linh, L.T. (2020), "Emission inventories of rice straw open burning in the Red River Delta of Vietnam: evaluation of the potential of satellite data", Environmental Pollution, Vol. 260, pp. 113972-113986, doi: 10.1016/j.envpol.2020.113972.

MONRE (2016), Environmental Status of Vietnam in the Period of 2011-2015, Ministry of Natural Resources and Environment (MONRE), Hanoi.

MONRE (2021), Document 3051/BTNMT-TCMT: Technical Guidance on Formulation of Provincial Air Quality Management Plan, Ministry of Natural Resources and Environment (MONRE), Hanoi.

Reşitoğlu, İ.A., Altinişik, K. and Keskin, A. (2015), "The pollutant emissions from diesel-engine vehicles and exhaust after treatment systems", Clean Technologies and Environmental Policy, Vol. 17 No. 1, pp. 15-27, doi: 10.1007/s10098-014-0793-9.

Thach, N. (2014), "The solutions to reduce emissions from marine engines", Science and Technology Development Journal, Vol. 17 No. 4, pp. 5-13, doi: 10.32508/stdj.v17i4.1525.

Trinh, T.P., Luong, H.D., Le, T.N. and Tran, D.T. (2017), "Impact of large reservoirs system on flow regime in the Red River basin", Vietnam Journal of Science and Technology (Version B), Vol. 18 No. 7, pp. 5-9, available at: https://b.vjst.vn/index.php/ban_b/article/view/382.

US EPA (2009), "Current methodologies in preparing mobile source port-related emission inventories", available at: https:/www.epa.gov/sites/default/files/2016-06/documents/2009-port-inventoryguidance.pdf (accessed 12 February 2021). 
FEBE

2,2

\section{6}

VMHA (2021), Monitoring Data of Hydrological Parameters of the Red River (The Section Flowing through Hanoi) in 2020, Viet Nam Meteorological and Hydrological Administration (VMHA), Hanoi.

Winijkul, E. (2020), "Emissions inventory for inland water transport in Bangkok, Thailand", available at: https://www.ccacoalition.org/en/resources/emissions-inventory-inland-water-transportbangkok-thailand (accessed 15 August 2021).

\section{Corresponding author}

Anh Le Hoang can be contacted at: leha@vnu.edu.vn

For instructions on how to order reprints of this article, please visit our website: www.emeraldgrouppublishing.com/licensing/reprints.htm Or contact us for further details: permissions@emeraldinsight.com 